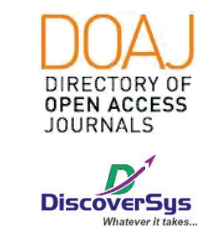

Published by DiscoverSys

\section{Karakteristik penderita polip hidung di poliklinik THT-KL RSUP Sanglah Denpasar tahun 2018}

\author{
I Made Surya Vedo Wirananda, ${ }^{1 *}$ Agus Rudi Asthuta, ${ }^{2}$ \\ Komang Andi Dwi Saputra ${ }^{3}$
}

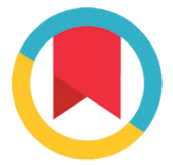

CrossMark

\title{
ABSTRACT
}

Introduction: Nasal polyps might trigger physical disorders and disrupt the normal function of daily life, causing decreases in productivity. Prevention and good management of nasal polyp cases become important. Therefore, information related to sociodemographic information is necessary even though the data available were still lacking.

Method: This descriptive research was done using a cross sectional design, which data were collected retrospectively. The research data were secondary data of patients' medical records in ENT poly in RSUP Sanglah Denpasar. This research describes the data related to nasal polyp patients in Sanglah Depansar, 2018 based on age, sex, main symptoms, comorbidities, and therapy. Research samples were selected using total sampling technique, in which the whole population that matched the predetermined criteria were involved in this research as samples.

Result: 27 data met the inclusion criteria. Nasal polyp mostly occurred in the group of 40-60 years old patients as many as
11 persons (40.7\%), with the youngest patient aged 10 years old. The results also indicated that the number of Nasal polyp in males reached 20 patients (74.1\%) than in females of 7 people (25.9\%). Nasal congestion was the main symptoms experienced by 15 people $(55.6 \%)$, while sinusitis was the highest risk factor that occurred to 16 patients (59.3\%). It was also found that rhinitis allergy was experienced by 7 patients (25.9\%). Furthermore, 4 patients (14.8\%) patients had rhinitis \& sinusitis risk factor. There were 9 patients (33.3\%) who underwent medical therapy, while 18 patients (66.7\%) had undergone medical therapy and surgery.

Conclusion: The highest frequency of polyp patient in RSUP Sanglah Denpasar of 2018 was found in the group of patients aged between 46-50 years old ( $40.7 \%)$, The number of Nasal polyps was found higher in male patients (74.1\%). Nasal congestion was the most common complaint $(55,6 \%)$, while the most frequently-risk factor was sinusitis (59.3\%). This research has confirmed that medicine and surgery were the most preferred nasal polyps therapy (66.7\%).

Keywords: Nasal polyp, age, sex, major symptom, comorbidities, therapy Cite This Article: Wirananda, I.M.S.V., Asthuta, A.R., Saputra, K.A.D. 2019. Karakteristik penderita polip hidung di poliklinik THT-KL RSUP Sanglah Denpasar tahun 2018. Intisari Sains Medis 10(3): 781-784. D0I: 10.15562/ism.v10i3.454

ABSTRAK

Latar Belakang: Polip hidung dapat menyebabkan gangguan fisik dan gangguan fungsi normal kehidupan sehari-hari sehingga menyebabkan penurunan produktivitas. Pencegahan dan penanganan yang tepat terhadap polip nasi sangat penting, sehingga informasi mengenai faktor sosio-demografi polip nasi sangat dibutuhkan walaupun data yang tersedia masih jarang

Metode: Rancangan penelitian ini bersifat deskriptif dengan rancangan penelitian cross sectional dengan pengambilan data secara retrospektif. Data yang digunakan berupa data sekunder yang didapat dari rekam medis pasien poli THT RSUP Sanglah Denpasar. Rancangan penelitian ini bertujuan untuk dapat menggambarkan penderita Polip Nasi di RSUP Sanglah Denpasar tahun 2018 berdasarkan usia, jenis kelamin, keluhan utama, penyakit penyerta dan terapi. Teknik penentuan sampel yang digunakan adalah total sampling dimana seluruh populasi target yang memenuhi kriteria dimasukan sebagai sampel.

Hasil: Sebanyak 27 data yang memenuhi kriteria inklusi. Berdasarkan kelompok usia angka kejadian terbanyak terjadi pada kelompok usia 46-
60 tahun (40,7\%) dengan usia termuda yaitu 10 tahun. Angka kejadian pada laki-laki lebih banyak dari pada perempuan yaitu jumlah angka kejadian pada laki-laki sebanyak 20 orang (74,1\%), perempuan 7 orang $(25,9 \%)$. Hidung tersumbat merupakan keluhan utama yang paling banyak terjadi yaitu pada 15 orang $(55,6 \%)$ dengan sinusitis sebagai faktor resiko tertinggi yang terjadi pada 16 orang (59,3\%), sedangkan faktor resiko berupa rhinitis allergi didapatkan data sebanyak 7 orang $(25,9 \%)$ dan pada faktor resiko rhinitis \& sinusitis didapatkan 4 orang $(14,8 \%)$. Pasien yang melakukan terapi medikamentosa didapatkan sebanyak 9 orang (33,3\%), pada terapi medikamentosa \& pembedahan didapatkan sebanyak 18 orang $(66,7 \%)$.

Simpulan: Distribusi frekuensi penderita polip nasi di RSUP Sanglah Denpasar tahun 2018 terbanyak berdasarkan kelompok usia yaitu kelompok usia 46-60 tahun (40,7\%), angka kejadian pada laki-laki lebih banyak $(74,1 \%)$, hidung tersumbat merupakan keluhan utama yang paling sering terjadi $(55,6 \%)$ dengan sinusitis sebagai faktor resiko yang paling sering ditemukan $(59,3 \%)$ dan terapi polip nasi berupa medikamentosa \& pembedahan $(66,7 \%)$. 
Kata kunci: Polip nasi, usia, jenis kelamin, keluhan utama, faktor resiko, terapi

Cite Pasal Ini: Wirananda, I.M.S.V., Asthuta, A.R., Saputra, K.A.D. 2019. Karakteristik penderita polip hidung di poliklinik THT-KL RSUP Sanglah Denpasar tahun 2018. Intisari Sains Medis 10(3): 781-784. D0I: 10.15562/ism.v10i3.454

\section{PENDAHULUAN}

Polip nasi merupakan masalah medis dan masalah sosial karena dapat mempengaruhi kualitas hidup penderita baik dari segi pendidikan, pekerjaan, aktifitas harian dan kenyamanan. Polip nasi merupakan salah satu penyakit THT yang sudah umum di dengar oleh masyarakat. ${ }^{1}$ Polip nasi merupakan mukosa hidung yang mengalami inflamasi dan menimbulkan prolaps mukosa di dalam rongga hidung. Polip nasi ini dapat dilihat melalui pemeriksaan rinoskopi dengan atau tanpa bantuan endoskop. $^{2}$

Polip nasi sering ditemukan pada penderita penyakit seperti rhinitis alergi, asma bronkiale, allergik fungal sinusitis, rinosinusitis kronik, aspirin intolerance, alkohol intolerance, young syndrome, dll. Pada anamnesis kasus polip biasanya timbul keluhan utama adalah hidung tersumbat. Sampai saat ini para pakar belum mendapatkan jawaban secara pasti apa yang mendasari munculnya benjolan putih keabu-abuan bertangkai itu. Namun dari studi dan pengamatan medis, baru ditemukan ada sejumlah faktor yang memudahkan pemunculan benjolan itu. Antara lain radang kronis yang berulang pada mukosa hidung dan sinus paranasal, gangguan keseimbangan vasomotor, peningkatan cairan interstitial serta odema (pembengkakan) mukosa hidung. ${ }^{3}$

Prevalensi penderita polip nasi belum diketahui pasti karena hanya sedikit laporan dari hasil studi epidemiologi serta tergantung pada pemilihan populasi penelitian dan metode diagnostik yang digunakan. Prevalensi polip nasi dilaporkan $1-2 \%$ pada orang dewasa di Eropa dan 4,3\% di Finlandia. Dengan perbandingan pria dan wanita 2-4:1. ${ }^{4}$ Di Amerika Serikat prevalensi polip nasi diperkirakan antara 1-4 \%. Pada anak-anak sangat jarang ditemukan dan dilaporkan hanya sekitar $0,1 \% .^{5} \mathrm{Di}$ Indonesia menunjukkan bahwa perbandingan pria dan wanita 2-3:1 dengan prevalensi 0,2\%-4,3\%. Di RSUP H. Adam Malik Medan selama Januari 2003 sampai Desember 2003 didapatkan kasus polip nasi sebanyak 32 orang terdiri dari 20 pria dan 12 wanita. ${ }^{6}$ Penelitian oleh Bachert selama Maret 2004 sampai Februari 2005 didapatkan kasus polip nasal sebanyak 26 orang terdiri dari 17 pria $(65 \%)$ dan 9 wanita $(35 \%){ }^{7}$ Penelitian oleh Stjarne selama September 2009 sampai Oktober 2010 didapatkan kasus polip nasal sebanyak 21 orang terdiri dari 15 pria $(71,4 \%)$ dan 6 wanita $(28.6 \%){ }^{8}$
Polip nasi sangat mengganggu pada kebanyakan pasien. Penyakit ini sering berulang dan memerlukan pengobatan yang lama sampai bertahun-tahun. Dengan demikian pengobatannya bertujuan untuk mengurangi besarnya atau menghilangkan polip agar aliran udara hidung menjadi lapang dan penderita dapat bernafas dengan baik. Selanjutnya gejala-gejala rinitis dapat dihilangkan dan fungsi penciuman kembali normal. Terdapat beberapa pilihan pengobatan untuk polip nasi mulai dari pemberian obat-obatan, pembedahan konvensional sederhana dengan menggunakan snare polip sampai pada bedah endoskopi yang memakai alat lebih lengkap. Walaupun demikian, angka kekambuhan masih tetap tinggi sehingga memerlukan sejumlah operasi ulang. ${ }^{9}$

\section{METODE}

Penelitian ini merupakan penelitian deskriptif dengan desain cross-sectional untuk untuk mengetahui Karakteristik penderita polip hidung di poliklinik THT-KL RSUP Sanglah Denpasar. Penelitian ini dilakukan di RSUP Sanglah Denpasar dari bulan September hingga Oktober tahun 2018

Sampel pada penelitian ini adalah pasien polip nasi yang terdata di buku registrasi di Poliklinik THT-KL RSUP Sanglah Denpasar tahun 2018, rakam medis pasien memiliki data lengkap meliputi nama, jenis kelamin, usia, keluhan utama datang ke rumah sakit, penyakit penyerta serta terapi polip nasi. 27 Sampel penelitian dipilih menggunakan metode total sampling. Variabel yang diteliti dalam penelitian ini yaitu usia, jenis kelamin, polip nasi, kadar kolesterol, keluhan utama, penyakit penyerta dan terapi.

Pengumpulan data dilakukan dengan menggunakan data sekunder melalui rekam medis pasien. Data yang diperoleh kemudian diolah dengan menggunakan bantuan piranti lunak SPSS ver. 21 . Data yang didapat akan dianalisa dan disajikan dalam bentuk table, diagram atau grafik disertai penjelasan untuk menentukan karakteristik penderita polip nasi.

\section{HASIL}

Tabel 1 menyajikan proporsi penderita polip nasi berdasarkan jenis kelamin nya di Poli THT-KL RSUP Sanglah Denpasar tahun 2018. Dapat dilihat bahwa distribusi frekuensi jenis kelamin dari 
Tabel 1 Jenis Kelamin Sampel Penelitian

\begin{tabular}{lcc}
\hline Jenis Kelamin & Frekuensi & Persentase (\%) \\
\hline Laki-Laki & 20 & $74.1 \%$ \\
Perempuan & 7 & $25.9 \%$ \\
Total & 27 & $100 \%$ \\
\hline
\end{tabular}

Tabel 2 Usia Sampel Penelitian

\begin{tabular}{lcccccc}
\hline Variabel & $\begin{array}{c}\text { Jumlah } \\
\text { (N) }\end{array}$ & $\begin{array}{c}\text { Rata- } \\
\text { rata }\end{array}$ & $\begin{array}{c}\text { Data } \\
\text { tengah }\end{array}$ & $\begin{array}{c}\text { Nilai } \\
\text { minimum }\end{array}$ & $\begin{array}{c}\text { Nilai } \\
\text { maksimum }\end{array}$ & p * $^{*}$ \\
\hline Usia & 27 & 44 & 48 & 10 & 75 & 0,123 \\
\hline
\end{tabular}

* uji Shapiro-wilk

Tabel 3 Keluhan Utama Sampel Penelitian

\begin{tabular}{lcc}
\hline Keluhan Utama & Frekuensi & Persentase (\%) \\
\hline Hidung Tersumbat & 15 & $55.6 \%$ \\
Hidung tersumbat \& Pilek & 7 & $25.9 \%$ \\
Hidung Tersumbat \& Sengau & 5 & $18.5 \%$ \\
Total & 27 & $100 \%$ \\
\hline
\end{tabular}

Tabel 4 Faktor Resiko Sampel Penelitian

\begin{tabular}{lcc}
\hline Faktor Resiko & Frekuensi & Persentase (\%) \\
\hline Rhinitis Allergi & 7 & $25.9 \%$ \\
Sinusitis & 16 & $59.3 \%$ \\
Rhinitis \& Sinusitis & 4 & $14.8 \%$ \\
Total & 27 & $100 \%$ \\
\hline
\end{tabular}

Tabel 5 Terapi Sampel Penelitian

\begin{tabular}{lcc}
\hline Terapi & Frekuensi & Persentase (\%) \\
\hline Medikamentosa & 9 & $33.3 \%$ \\
Medikamentosa \& Pembedahan & 18 & $66.7 \%$ \\
Total & 27 & $100 \%$ \\
\hline
\end{tabular}

sampel adalah 7 (25.9 \%) pada perempuan dan $20(74.1 \%)$ untuk jenis kelamin laki-laki.

Rerata usia adalah 44 tahun. Lalu didapatkan data tengah dengan usia 48 tahun, selain itu didapatkan nilai minimum dan maksimum dengan usia 10 tahun dan 75 tahun. Dikarenakan data usia adalah variabel numerikal dilakukan juga uji normalitas untuk mengetahui distribusi dari data tersebut. Uji normalitas yang dipilih adalah uji Shapiro-wilk dikarenakan jumlah data kurang dari 50. Hasil yang didapatkan dari uji normalitas adalah $\mathrm{p}=0.123(\mathrm{p}>0,05)$ maka data usia berdistribusi normal (Tabel 2).

Keluhan yang sering dialami adalah hidung tersumbat sebanyak 15 penderita (55.6\%), dilanjutkan dengan hidung tersumbat \& pilek sebanyak 7 penderita $(25.9 \%)$, sedangkan yang paling sedikit adalah hidung tersumbat \& sengau sebanyak 5 penderita (18.5\%) (Tabel 3). Dari data yang ada didapatkan sebanyak $16(59.3 \%)$ pasien memiliki faktor resiko sinusitis, dilanjutkan rhinitis allergi sebanyak 7 (25.9\%), rhinitis \& Allergi sebanyak 4 pasien (14.8\%) (Tabel 4). Medikamentosa \& pembedahan merupakan terapi yang paling sering dilakukan dengan frekuensi sebanyak 18 (66.7\%), sedangkan terapi medikamentosa saja didapatkan 9 frekuensi dengan persentasi (33.3\%) (Tabel 5).

\section{DISKUSI}

Pada penelitian ini ditemukan lebih banyak sampel memiliki jenis kelamin laki-laki dengan jumlah 20 (74.1\%) sampel dibanding jenis kelamin perempuan dengan jumlah 7 (25.9\%) sampel. Hal ini serupa dengan penelitian yang dilakukan oleh stjarne (2007) dimana ditemukan lebih banyak pada laki-laki dengan jumlah 17 (65\%) dari total 26 sampel dan pada perempuan sebanyak 9 (35\%) dari total sampel. ${ }^{8}$ Mourina pada tahun 2012 juga mengatakan bahwa didapatkan sampel sebanyak 59 orang penderita polip hidung yang terdiri dari laki-laki 36 orang (61\%), perempuan 23 orang (39\%) dengan perbandingan 1.6:1. ${ }^{6}$

Rentang usia 46-60 tahun merupakan kelompok usia yang paling banyak menderita polip nasi yakni sebanyak $11(40.7 \%)$ dengan usia termuda yaitu 10 tahun. Sedangkan menurut penelitian Mourina (2012) juga mengatakan Kelompok umur paling banyak terdapat pada golongan umur 45- 54 tahun (27.1\%) dengan umur termuda yaitu 9 tahun dan yang tertua adalah umur 83 tahun. ${ }^{6}$

Keluhan utama yang terjadi pada penderita polip nasi adalah hidung tersumbat $(55,6 \%)$ mengalami hidung tersumbat. Hasil penelitian ini selajan dengan penelitian Mourina (2012) yang mendapatkan keluhan utama terbanyak yaitu hidung tersumbat (98.3\%). ${ }^{6}$ Gevaert pada tahun 2005 juga megatakan bahwa keluhan yang sering dilaporkan yaitu hidung tersumbat." Penelitian ini sesuai dengan teori yang diungkapkan Spafford (2002) bahwa gejala utama yang paling sering yaitu hidung tersumbat. ${ }^{10}$

Resiko polip nasi tertinggi yaitu sinusitis (59.3\%). Penelitian ini sejalan dengan yang dilakukan oleh Mourina (2012) bahwa sebanyak 33 orang dari 47 sampel (70.2\%). ${ }^{6}$ Lalu pada penelitian Kim \& Hanley (2002) juga mengatakan bahwa polip hidung paling sering terjadi diakbatkan sinusitis kronis yaitu sebanya 40 orang dari 55 orang yang di teliti (73\%). ${ }^{11}$ Stjarne (2007) juga mengungkapkan bahwa etiologi yang sering dikaitkan dengan polip hidung adalah sinusitis. ${ }^{8}$

Terapi yang paling banyak dilakukan pada pasien polip nasi yaitu menjalani terapi medikamentosa 
dan terapi bedah (66.7\%). $33.3 \%$ sisa nya hanya diterapi dengan menggunakan terapi medikamentosa. Penelitian ini ternyata sejalan dengan prinsip pengobatan polip hidung menurut Assanassen \& Naclerio (2001) yaitu pemberian obat-obatan terlebih dahulu seperti kortikosteroid dan antibiotik kemudian melakukan operasi setelah itu pemberian kortikosteroid lagi untuk mencegah rekurensi. ${ }^{12}$ Penelitian oleh Mourina (2012) didapatkan hampir semua pasien polip hidung yang menjalani terapi medikamentosa dan terapi bedah yaitu 54 orang (94.1\%) dan 5 orang lainnya hanya diberikan penatalaksanaan medikamentosa (8.5\%). ${ }^{6}$

\section{SIMPULAN}

Dari hasil penelitian ini jumlah kasus polip nasi di Poliklinik RSUP Sanglah Denpasar tahun 2018 sebanyak 27 kasus, laki-laki $74.1 \%$ dan perempuan $25.9 \%$. Kelompok usia yang paling sering yaitu 46-60 tahun (40.7 \%). Keluhan utama yang paling banyak dikeluhkan pada penderita polip nasi adalah hidung tersumbat (55,6\%). Faktor resiko polip nasi tertinggi yaitu sinusitis (59.3\%). Proporsi pasien polip hidung yang menjalankan terapi medikamentosa terlebih dahulu kemudian menjalankan tindakan operasi adalah $66.7 \%$.

\section{KONFLIK KEPENTINGAN}

Penulis menyatakan tidak terdapat suatu konflik kepentingan terhadap publikasi dari artikel ini.

\section{PENDANAAN}

Penelitian ini tidak mendapatkan suatu pendanaan yang diberikan oleh pemerintah ataupun lembaga swasta lainnya.

\section{KONTRIBUSI PENULIS}

Konsep penelitian: I Made Surya Vedo Wirananda, Agus Rudi Asthuta, Komang Andi Dwi Saputra.
Pengumpulan data, input data dan pengolahan data: I Made Surya Vedo Wirananda. Penyusunan naskah Penelitian: I Made Surya Vedo Wirananda.

\section{ETHICAL CLEARANCE NUMBER}

1261/UN14.2.2/PD/KEP/2018.

\section{DAFTAR PUSTAKA}

1. Lubis A., Munir D., Nursiah S., Kusumawati R., Eyanoer P. The aerobic-anaerobic bacteria pattern and its sensitivity pattern in chronic rhinosinusitis patients, in Medan, Indonesia. Bali Medical Journal. 2018. 7(1): 51-55. DOI: 10.15562/bmj.v7i1.801

2. Newton JR. \& Ah-See KW., A review of nasal polyposis. Therapeutics and Clinical Risk Management. 2008. 4(2), p.507-512.

3. Kirtsreesakul V., Update on nasal polyps: Etiopathogenesis. Journal of the Medical Association of Thailand. 2005. 88(12), p.1966-1972.

4. Erbek SS. et al., The role of allergy in the severity of nasal polyposis. American journal of rhinology. 2007. 21(6), p.686-90. Available at: http://www.ncbi.nlm.nih.gov/ pubmed/17883886.

5. Pawliczak R., Lewandowska-Polak A. \& Kowalski ML., Pathogenesis of nasal polyps: an update. Current allergy and asthma reports. 2005. 5(6), p.463-71. Available at: http://www.ncbi.nlm.nih.gov/pubmed/16216171.

6. Mourina S. Karakteristik Dan Penatalaksanaan Penderita Polip Hidung Di Rsup H. Adam Malik Medan Tahun 2009-2011. repository USU. 2012

7. Bachert C. et al. Pharmacological management of nasal polyposis. Drugs. 2005.65(11), p.1537-1552.

8. Stjarne, Par. Momentosa Furoate Nasal Spray for the Treatment of Nasal Polyposis. Karolinska University Hospital. 2007.

9. Gevaert P. et all. Chronic Rhinosinusitis and Nasal Polyposis. World Allergy.2005.

10. Spafford P. Dealing With Nasal Polyps. The Canadian Journal of CME. 2002.

11. Kim J., Hanley JA. The Rule OF Woodstoves In Etiology of Nasal Polypsposis. 2002.

12. Assanasen P. \& Naclerio RM. Medical and surgical management of nasal polyps. 2001. 27-36.

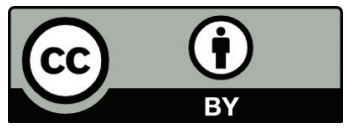

This work is licensed under a Creative Commons Attribution 